\title{
Down-regulation of thymic stromal lymphopoietin by curcumin
}

\author{
Phil-Dong Moon ${ }^{1}$, Hyun-Ja Jeong ${ }^{2}$, Hyung-Min Kim¹ \\ ${ }^{1}$ Department of Pharmacology, College of Oriental Medicine, Institute of Oriental Medicine, Kyung Hee University, \\ 1 Hoegi-dong, Dongdaemun-gu, Seoul 130-701, Republic of Korea \\ ${ }^{2}$ Biochip Research Center, Hoseo University, 165, Sechul-ri, Baebang-myun, Asan, Chungnam 336-795, \\ Republic of Korea
}

Correspondence: Hyun-Ja Jeong or Hyung-Min Kim, e-mail: hjjeong@hoseo.edu or hmkim@khu.ac.kr

\begin{abstract}
:
Background: Thymic stromal lymphopoietin (TSLP) is a cytokine implicated in the pathogenesis of allergic diseases such as asthma, atopic dermatitis and allergic rhinitis. Curcumin has various effects such as antidepressant, antioxidant, antihyperglycemic, antitumor and anti-inflammatory. However, the effect of curcumin on the production of TSLP has not been clarified. Thus, we investigated how curcumin inhibits the expression and production of TSLP in the human mast cell line, HMC-1 cells.

Methods: We used enzyme-linked immunosorbent assay, reverse transcription-polymerase chain reaction, luciferase assay, and caspase-1 assay to investigate the effects of curcumin.

Results: The results show that curcumin inhibited the production and mRNA expression of TSLP in HMC-1 cells: the maximal inhibition rate of TSLP production by curcumin $(50 \mu \mathrm{M})$ was $59.16 \pm 4.20 \%$. In addition, curcumin suppressed the nuclear factor- $\mathrm{kB}$ luciferase activity induced by phorbol myristate acetate plus A23187. In the activated HMC-1 cells, caspase-1 activity was increased, whereas caspase-1 activity was decreased by pretreatment with curcumin.
\end{abstract}

Conclusion: These results suggest that curcumin can be used to treat inflammatory and atopic diseases through the suppression of TSLP.

Key words: thymic stromal lymphopoietin, curcumin, nuclear factor- $\kappa \mathrm{B}$, caspase-1 Abbreviations: NF- $\kappa \mathrm{B}-$ nuclear factor- $\mathrm{\kappa B}$, PMA - phorbol
myristate acetate, TSLP - thymic stromal lymphopoietin

\section{Introduction}

Atopic dermatitis is a chronic and relapsing eczematous skin inflammation associated with epidermal barrier dysfunction, intense pruritus, and cutaneous hyperreactivity to environmental triggers [8]. The lifetime prevalence of atopic dermatitis is estimated to be $15-30 \%$ in children and $2-10 \%$ in adults, while the incidence of atopic dermatitis has increased 2- to 3fold during the past 3 decades in industrialized countries [1]. Thus, atopic dermatitis has significant socioeconomic and personal impacts in these countries [21].

Thymic stromal lymphopoietin (TSLP) was found to enhance potently the maturation of $\mathrm{CD} 11 \mathrm{c}^{+}$dendritic cells, and TSLP-primed and activated dendritic cells promoted the differentiation of naive $\mathrm{CD}^{+} \mathrm{T}$ 
<smiles>COc1cc(/C=C/C(=O)CC(=O)/C=C/c2ccc(O)c(OC)c2)ccc1O</smiles>

Fig. 1. Chemical structure of curcumin

cells into proinflammatory $\mathrm{T}_{\mathrm{H}} 2$ cells [20]. A high expression of TSLP is a feature of keratinocytes in atopic dermatitis skin lesions, and the TSLP-priming of dendritic cells in situ may serve to induce or enhance $\mathrm{T}_{\mathrm{H}} 2$ responses within the skin, as well as systemically. Consistent with this viewpoint, TSLP was originally reported to exert its $\mathrm{T}_{\mathrm{H}} 2$-promoting properties through dendritic cell-mediated pathways in human beings that involved the induction of the OX40 ligand on dendritic cells [28]. TSLP has been implicated in the development of asthma and atopic dermatitis [13]. In atopic diseases such as asthma and atopic dermatitis, not only dendritic cells, epithelial cells, eosinophils, and T cells but also mast cells are important. A number of studies reported that mast cells are activated and infiltrated in the skin lesion of the atopic dermatitis animal model, suggesting the contribution of mast cells in atopic dermatitis $[4,9,25,30]$.

The cysteine protease caspase- 1 is a member of the caspase family [6]. Quite unlike the role that most caspases have in apoptosis, caspase-1 mainly serves to cleave IL-1 $\beta$ and IL-18 from their inactive precursors to their active forms $[2,16]$. In addition to the wellestablished roles of caspase 1 in the maturation of IL- $1 \beta$ and IL-18, caspase 1 is also capable of activating the nuclear factor (NF)-кB [15]. The activated caspase-1 acti-

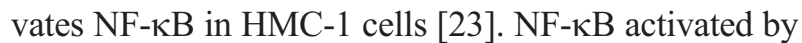
caspase-1 mediates the induction of TSLP gene expression in airway epithelial cells [18].

Curcumin (Fig. 1) is the main constituent of the spice turmeric (Curcuma longa) [7, 33]. A number of studies have reported that curcumin has antidepressant, antioxidant, antihyperglycemic, antitumor, and anti-inflammatory activities $[5,10,19,29,32]$. However, the effect of curcumin on the production of TSLP has not yet been clarified. Thus, we investigated how curcumin suppresses the production of TSLP in mast cells.

\section{Materials and Methods}

\section{Reagents}

Phorbol myristate acetate (PMA), A23187, and curcumin were purchased from Sigma Chemical Co. (St. Louis, MO, USA). We purchased IMDM from Gibco BRL (Grand Island, NY, USA); caspase-1 inhibitor, caspase-1 assay kit, and TSLP antibodies from R\&D Systems (Minneapolis, MN, USA); TMB substrate from Pharmingen (San Diego, CA, USA).

\section{Cell culture}

The human mast cell line, HMC-1 cells, was grown in IMDM and supplemented with 100 units/ml of penicillin, $100 \mu \mathrm{g} / \mathrm{ml}$ of streptomycin and $10 \%$ fetal bovine serum at $37^{\circ} \mathrm{C}$ in $5 \% \mathrm{CO}_{2}$ with $95 \%$ humidity.

\section{Cytokine assay}

We used the enzyme-linked immunosorbent assay (ELISA) method to assay the culture supernatant for TSLP $[22,24]$. A sandwich ELISA for TSLP was carried out in duplicate in a 96-well ELISA plate. First, we coated the plate with $100 \mu \mathrm{l}$ aliquots of mouse anti-human TSLP monoclonal antibody at $1.0 \mu \mathrm{g} / \mathrm{ml}$ in PBS at $\mathrm{pH} 7.4$ and incubated the plate overnight at $4^{\circ} \mathrm{X}$. The plate was washed in PBS containing $0.05 \%$ Tween-20 (Sigma) and blocked with PBS containing $1 \%$ BSA, $5 \%$ sucrose and $0.05 \% \mathrm{NaN}_{3}$ for $1 \mathrm{~h}$. After additional washes, the culture supernatant and TSLP standards were added and incubated at $37^{\circ} \mathrm{C}$ for $2 \mathrm{~h}$. After $2 \mathrm{~h}$ incubation at $37^{\circ} \mathrm{C}$, the wells were washed and then each of the $0.2 \mu \mathrm{g} / \mathrm{ml}$ of biotinylated antihuman TSLP was added and again incubated at $37^{\circ} \mathrm{C}$ for $2 \mathrm{~h}$. After washing the wells, streptavidinperoxidase was added and the plate was incubated for $20 \mathrm{~min}$ at $37^{\circ} \mathrm{C}$. The wells were again washed and the TMB substrate (Pharmingen) was added. Color development was measured at $450 \mathrm{~nm}$ using an automated microplate ELISA reader. A standard curve was run on the plate using recombinant human TSLP in serial dilutions. 


\section{Reverse transcription-polymerase chain reaction (RT-PCR) analysis}

We used the method of Moon et al. [22], using an easy-BLUETM RNA extraction kit (iNtRON Biotech, Republic of Korea) and isolated the total RNA from HMC-1 cells in accordance with the manufacturer's specifications. The concentrations of total RNA in the final elutes were determined by a spectrophotometer. Total RNA $(1 \mu \mathrm{g})$ was heated at $65^{\circ} \mathrm{C}$ for $10 \mathrm{~min}$ and then chilled on ice. Each sample was reversetranscribed to cDNA for $90 \mathrm{~min}$ at $37^{\circ} \mathrm{C}$ using a cDNA synthesis kit (Amersham Pharmacia Biotech, Piscataway, NJ, USA). The PCR was performed with the following primer for human TSLP (5'TAT GAG TGG GAC CAA AAG TAC CG3'; 5'GGG ATT GAA GGT TAG GCT CTG G3'). GAPDH (5'CAA AAG GGT CAT CAT CTC TG3'; 5'CCT GCT TCA CCA CCT TCT TG3') was used to verify if equal amounts of RNA were used for reverse transcription and PCR amplification from different experimental conditions. The annealing temperature was $62^{\circ} \mathrm{C}$ for TSLP and GAPDH. Amplified fragment sizes for TSLP and GAPDH were 97 bp and 446 bp, respectively. Products were electrophoresed on a $1.5 \%$ agarose gel and visualized by staining with ethidium bromide.

\section{Transient transfection and luciferase assay}

For the transfection, we seeded HMC-1 cells $\left(1 \times 10^{7}\right)$ in a $100 \mathrm{~mm}$ culture dish. We then used Lipofectamine ${ }^{\mathrm{TM}} 2000$ purchased from Invitrogen (Carlsbad, $\mathrm{CA}, \mathrm{USA}$ ) to transiently transfect $\mathrm{pNF}-\kappa \mathrm{B}$ luciferase (LUC) and pSV40-LUC reporter gene constructs into HMC-1 cells. To measure the luciferase activity, we used a luminometer 1420 luminescence counter purchased from Perkin Elmer (Waltham, MA, USA) in accordance with the manufacturer's protocols. All the transfection experiments were performed in at least three different experiments, with similar results. The relative luciferase activity was defined as the ratio of firefly luciferase activity to renilla luciferase activity.

\section{Caspase-1 assay}

Caspase activity was measured according to the manufacturer's specifications by using a caspase assay kit. The whole-cell lysate was prepared in a cold lysis buffer on ice for $10 \mathrm{~min}$ and centrifuged at $12,000 \times \mathrm{g}$ for $1 \mathrm{~min}$. An equal amount of total protein was quantified by a bicinchoninic acid protein quantification kit purchased from Sigma Chemical Co. (St. Louis, MO, USA) in each lysate. The catalytic activity of caspase-1 from the cell lysate was measured by the proteolytic cleavage of WEHD-p-nitroaniline (pNA, caspase-1 colorimetric substrate) for $24 \mathrm{~h}$ at $37^{\circ} \mathrm{C}$. The plates were read at $405 \mathrm{~nm}$. The recombinant caspase-1 enzyme was available as a positive control.

\section{Statistical analysis}

All results are expressed as the mean \pm SEM. The statistical evaluation of the results was performed by an independent $t$-test and an ANOVA with a Tukey post$h o c$ test. The results were significant with a value of $\mathrm{p}<0.05$.

\section{Results}

\section{Effect of curcumin on the production of TSLP in HMC-1 cells}

To investigate the inhibitory effect of curcumin on the production of TSLP, we stimulated HMC-1 cells with PMA plus A23187 for $7 \mathrm{~h}$, and we used the ELISA to analyze the supernatants for TSLP. The stimulation with PMA plus A23187 increased TSLP production from HMC-1 cells (Fig. 2A). The levels of TSLP which had increased due to PMA plus A23187 were significantly decreased by curcumin $(50 \mu \mathrm{M})$ (Fig. $2 \mathrm{~A}, \mathrm{p}<0.05)$. The maximal inhibition rate of TSLP production by curcumin $(50 \mu \mathrm{M})$ was $59.16 \pm 4.20 \%$. In previous study, we reported that caspase- 1 is involved in the production of TSLP [23]. Thus, we confirmed the inhibition of TSLP production by the caspase-1 inhibitor in HMC-1 cells (Fig. 2A). The caspase-1 inhibitor reduced TSLP production up to $62.26 \pm 0.82 \%$. When curcumin was given as a pretreatment at various concentrations ranging from 0.5 to $50 \mu \mathrm{M}$, the cytotoxicity due to curcumin was not shown (data not shown).

\section{Effect of curcumin on the mRNA expression of TSLP in HMC-1 cells}

To examine whether curcumin can modulate PMA plus A23187-induced mRNA expression of TSLP, we pretreated the cells with curcumin for $2 \mathrm{~h}$ before the 


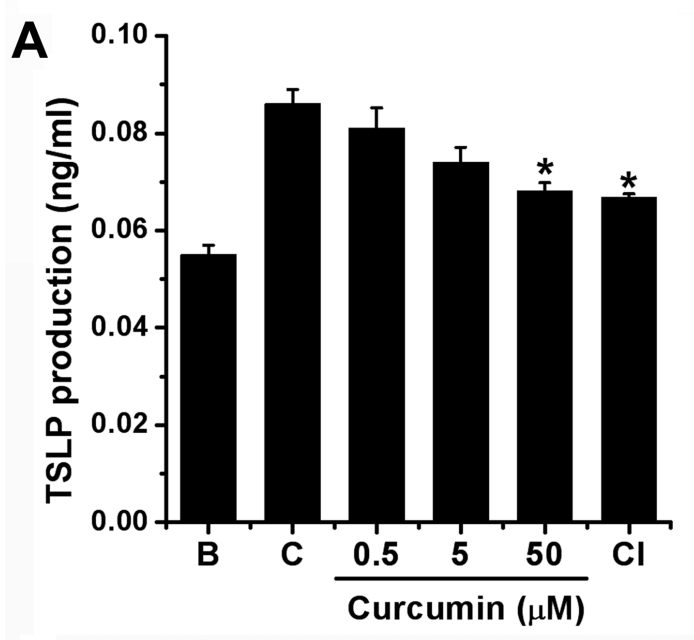

B
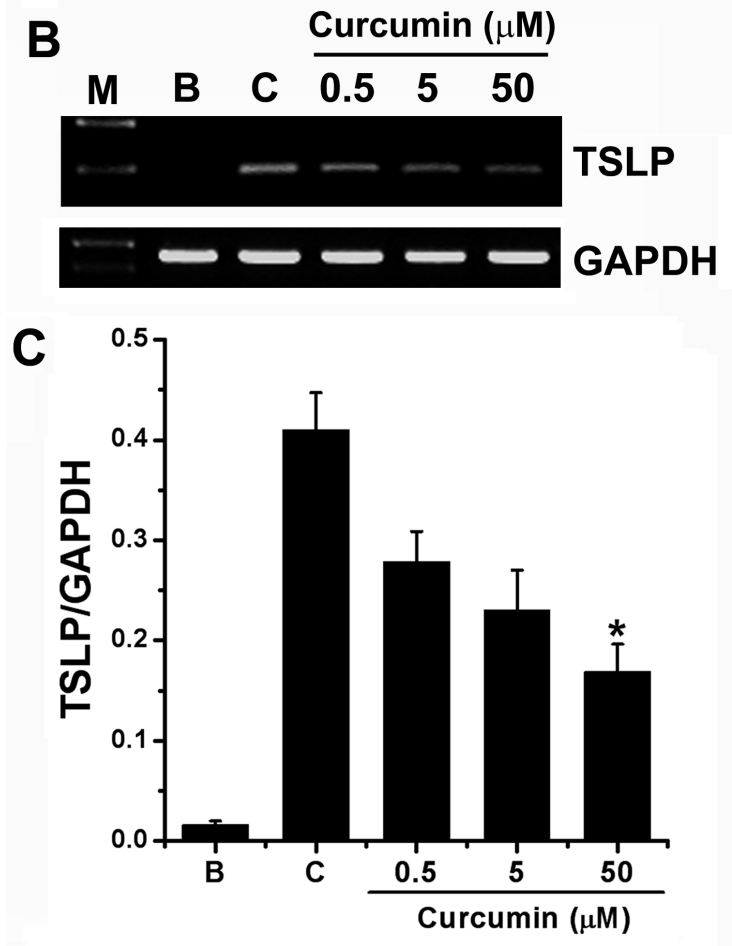

Fig. 2. Effects of curcumin on the production and mRNA expression of TSLP in HMC-1 cells. (A) HMC-1 cells $\left(4 \times 10^{5}\right)$ were treated with various concentrations $(0.5$ to $50 \mu \mathrm{M})$ of curcumin for $2 \mathrm{~h}$, and then stimulated with PMA plus A23187 for $7 \mathrm{~h}$. The levels of TSLP in the supernatant were measured with the ELISA method. B, unstimulated cells; C, vehicle-treated, and then PMA plus A23187-stimulated cells. $\mathrm{Cl}$, caspase-1 inhibitor (500 nM)-treated, and then PMA plus A23187-stimulated cells. (B) HMC-1 cells $\left(1 \times 10^{6}\right)$ were stimulated with PMA plus A23187. The mRNA was measured with the RT-PCR method. M, marker. (C) The TSLP mRNA expression levels were quantified by densitometry

PMA plus A23187 stimulation. We stimulated the cells with PMA plus A23187 for $5 \mathrm{~h}$ and then performed the RT-PCR analysis. The mRNA expression of TSLP was up-regulated by PMA plus A23187; however, the up-regulated TSLP mRNA expression was decreased by the treatment with curcumin (Fig. 2B). The inhibitory effect of $50 \mu \mathrm{M}$ of curcumin was greater than 0.5 and $5 \mu \mathrm{M}$, thus, we evaluated the effect of $50 \mu \mathrm{M}$ of curcumin in the next set of experiments: luciferase assay and caspase- 1 assay.

\section{Effect of curcumin on the activation of NF- $\mathrm{KB}$ in HMC-1 cells}

To determine whether curcumin could modulate the luciferase expression specifically via $\mathrm{NF}-\kappa \mathrm{B}$ activation, we performed a dual-luciferase assay. As shown in Figure 3, the PMA plus A23187 stimulation increased the reporter gene activity. However, the increased $N F-\kappa B$ luciferase activity was significantly decreased by curcumin $(50 \mu \mathrm{M}, \mathrm{p}<0.05)$. The relative luciferase activity at the dose of $50 \mu \mathrm{M}$ was 22.31 \pm 0.80 . The control and spontaneous values were $32.75 \pm 1.20$ and $1.24 \pm 0.01$, respectively.

\section{Effect of curcumin on the activation of caspase-1 in HMC-1 cells}

Finally, to examine the effect of curcumin on the activation of caspase-1, we performed a caspase-1 assay on HMC-1 cells. In the control group that was stimulated by PMA plus A23187, the levels of caspase-1 activity were increased in HMC-1 cells. However, the levels of caspase-1 activity were decreased by pretreatment with curcumin (Fig. 4).

\section{Discussion}

Natural product-based compounds seem better than synthetic compounds because natural product-based compounds are generally supposed to be devoid of severe side effects [12]. Curcumin is the main constituent of the spice turmeric (Curcuma longa) [7, 33]. Therefore, we investigated the effect of the natural product-based compound curcumin on the expression and production of TSLP.

The PKC activator PMA is generally a substitute for diacylglycerol and A23187 is a widely used ionophore. Our previous study showed that TSLP is produced by PMA plus A23187 stimulation [23]. Lesional, but not unaffected, skin from patients with atopic dermatitis expresses high levels of TSLP [34]. In the present study, curcumin suppressed the production and mRNA expression of TSLP (Fig. 2). To our 


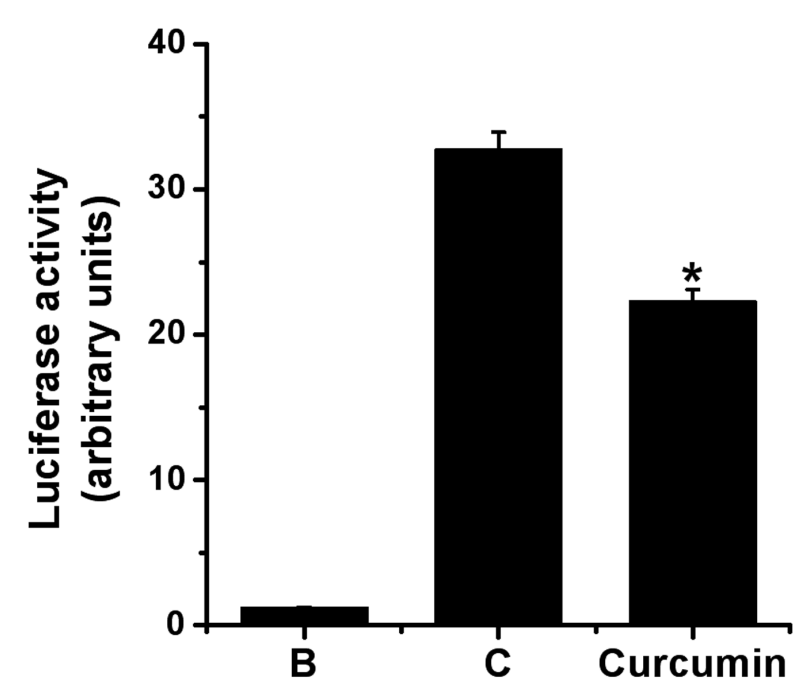

Fig. 3. Effects of curcumin on the activation of NF-kB in HMC-1 cells. HMC-1 cells $\left(1 \times 10^{7}\right)$ were transiently transfected with pNF-kB-LUC and pSV4O-LUC and treated with curcumin $(50 \mu \mathrm{M})$ for $2 \mathrm{~h}$, and then stimulated with PMA plus A23187 for $48 \mathrm{~h}$. The NF-kB activity was assessed with a luciferase assay. B, unstimulated cells; C, vehicletreated, and then PMA plus A23187-stimulated cells; Curcumin $50 \mu \mathrm{M}$ of curcumin-treated, and then PMA plus A23187-stimulated cells. Each datum represents the mean \pm SEM of three independent experiments. ${ }^{*} \mathrm{p}<0.05$; significantly different from the contro (vehicle-treated, and then PMA plus A23187-stimulated cells) value

knowledge, this is the first study showing an inhibition of TSLP by curcumin in mast cells. Thus, we presume that curcumin might have a potential in the treatment of inflammation and atopic dermatitis.

$\mathrm{NF}-\mathrm{\kappa B}$ is a transcription factor that regulates the expression of the genes involved in the immune response and inflammation [3]. It has been reported that the expression of human TSLP mRNA was controlled by NF- $\mathrm{KB}$ in various cells such as fibroblasts and epithelial cells $[17,18,26]$. The expression and production of TSLP was controlled by NF- $\kappa \mathrm{B}$ in mast cells [23]. Rafiee et al. [27] reported that curcumin inhibits NF- $\kappa \mathrm{B}$ activation in acid-activated HET-1A cells. In addition, curcumin inhibited NF- $\kappa \mathrm{B}$ binding activity in mice [31]. Our results also showed that curcumin inhibited the NF- $\mathrm{KB}$ luciferase activity in mast cells (Fig. 3). From previous reports and our results, we could confirm that NF- $\mathrm{KB}$ is a general transcription factor in fibroblasts, epithelial cells, and mast cells. In this study, curcumin inhibited NF- $\kappa B$ luciferase activity about $33 \%$. However, curcumin inhibited TSLP production about 59\%. Kouzaki et al. [14] reported that proteases induce TSLP production through the protease-activated receptor-2 (PAR-2). Thus, we can presuppose that curcumin inhibits TSLP

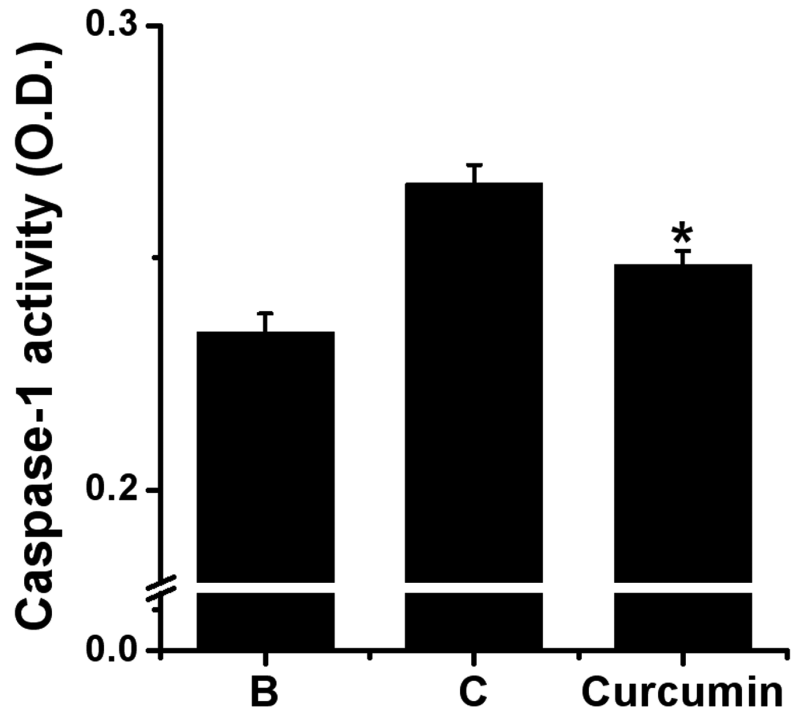

Fig. 4. Effects of curcumin on the activation of caspase- 1 in HMC-1 cells. HMC- 1 cells $\left(5 \times 10^{6}\right)$ were treated with $50 \mu \mathrm{M}$ of curcumin for $2 \mathrm{~h}$, and then stimulated with PMA plus A23187 for $1 \mathrm{~h}$. B, unstimulated cells; C, vehicle-treated, and then PMA plus A23187-stimulated cells; Curcumin, $50 \mu \mathrm{M}$ of curcumin-treated, and then PMA plus A23187-stimulated cells. Each datum represents the mean \pm SEM of three independent experiments. ${ }^{*} p<0.05$; significantly different from the control (vehicle-treated, and then PMA plus A23187-stimulated cells) value

production by the inhibition of not only NF- $\mathrm{KB}$ but also of the other mechanisms such as PAR-2.

Upon receipt of a pro-inflammatory stimulus, caspase-1 is activated [11]. Our results also showed that caspase-1 activity was increased by pro-inflammatory stimulus in HMC-1 cells (Fig. 4). In previous study, we reported that caspase-1 is involved in the production of TSLP [23]. Thus, we confirmed the inhibition of TSLP production by the caspase- 1 inhibitor in this study (Fig. 2A). Pretreatment of curcumin inhibited the PMA plus A23187-induced activation of caspase-1 (Fig. 4). To our knowledge, this is also the first study showing an inhibition of caspase-1 activity by curcumin in mast cells. Thus, we can assume that curcumin inhibits the expression and production of TSLP through the blocking of caspase-1 in mast cells.

In conclusion, we have shown that curcumin can regulate the inflammatory responses induced by PMA plus A23187 in mast cells. Curcumin suppressed the expression and production of TSLP through the blocking of caspase-1 and NF- $\mathrm{\kappa B}$ pathways. Overall, this study suggests that curcumin has potential in the treatment of inflammatory and atopic diseases through the suppression of TSLP. 


\section{Acknowledgments}

This research was supported by Basic Science Research Program through the National Research Foundation of Korea (NRF) funded by the Ministry of Education, Science and Technology (2010-0005591) and by a grant from the Kyung Hee University in 2011 (KHU-20110092)

\section{References:}

1. Bieber T: Atopic dermatitis. Ann Dermatol, 2010, 22, 125-137.

2. Boost KA, Hoegl S, Hofstetter C, Flondor M, Stegewerth K, Platacis I, Pfeilschifter J et al.: Targeting caspase-1 by inhalation-therapy: effects of Ac-YVAD$\mathrm{CHO}$ on IL-1 $\beta$, IL-18 and downstream proinflammatory parameters as detected in rat endotoxaemia. Intensive Care Med, 2007, 33, 863-871.

3. Cai Z, Zhao Y, Yao S, Bin Zhao B: Increases in $\beta$-amyloid protein in the hippocampus caused by diabetic metabolic disorder are blocked by minocycline through inhibition of NF- $\kappa$ B pathway activation. Pharmacol Rep, 2011, 63, 381-391.

4. Dumortier A, Durham AD, Di Piazza M, Vauclair S, Koch U, Ferrand G, Ferrero I et al.: Atopic dermatitislike disease and associated lethal myeloproliferative disorder arise from loss of Notch signaling in the murine skin. PLoS One, 2010, 5, e9258.

5. El-Moselhy MA, Taye A, Sharkawi SS, El-Sisi SF, Ahmed AF: The antihyperglycemic effect of curcumin in high fat diet fed rats. Role of TNF- $\alpha$ and free fatty acids. Food Chem Toxicol, 2011, 49, 1129-1140.

6. Gordon JR, Burd PR, Galli SJ: Mast cells as a source of multifunctional cytokines. Immunol Today, 1990, 11, 458-464.

7. Gradisar H, Keber MM, Pristovsek P, Jerala R: MD-2 as the target of curcumin in the inhibition of response to LPS. J Leukoc Biol, 2007, 82, 968-974.

8. Hartmann B, Riedel R, Jörß K, Loddenkemper C, Steinmeyer A, Zügel U, Babina $M$ et al.: Vitamin D receptor activation improves allergen-triggered eczema in mice. J Invest Dermatol, 2012, 132, 330-336.

9. Hong SW, Kim MR, Lee EY, Kim JH, Kim YS, Jeon SG, Yang JM et al.: Extracellular vesicles derived from Staphylococcus aureus induce atopic dermatitis-like skin inflammation. Allergy, 2011, 66, 351-359.

10. Hsu HY, Chu LC, Hua KF, Chao LK: Heme oxygenase-1 mediates the anti-inflammatory effect of curcumin within LPS-stimulated human monocytes. J Cell Physiol, 2008, 215, 603-612.

11. Humke EW, Shriver SK, Starovasnik MA, Fairbrother WJ, Dixit VM: ICEBERG: a novel inhibitor of interleukin-1 $\beta$ generation. Cell, 2000, 103, 99-111.

12. Jachak SM: Cyclooxygenase inhibitory natural products: current status. Curr Med Chem, 2006, 13, 659-678.

13. Kashyap M, Rochman Y, Spolski R, Samsel L, Leonard WJ: Thymic stromal lymphopoietin is produced by dendritic cells. J Immunol, 2011, 187, 1207-1211.

14. Kouzaki H, O'Grady SM, Lawrence CB, Kita H: Proteases induce production of thymic stromal lymphopoietin by airway epithelial cells through protease-activated receptor-2. J Immunol, 2009, 183, 1427-1434.

15. Lamkanfi M, Kalai M, Saelens X, Declercq W, Vandenabeele P: Caspase-1 activates nuclear factor of the $\kappa$-enhancer in B cells independently of its enzymatic activity. J Biol Chem, 2004, 279, 24785-24793.

16. Lamkanfi M, Kanneganti TD, Franchi L, Núñez G: Caspase-1 inflammasomes in infection and inflammation. J Leukoc Biol, 2007, 82, 220-225.

17. Lee HC, Headley MB, Iseki M, Ikuta K, Ziegler SF: Cut-

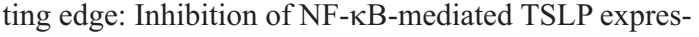
sion by retinoid $\mathrm{X}$ receptor. J Immunol, 2008, 181, 5189-5193.

18. Lee HC, Ziegler SF: Inducible expression of the proallergic cytokine thymic stromal lymphopoietin in airway epithelial cells is controlled by NFкB. Proc Natl Acad Sci USA, 2007, 104, 914-919.

19. Liao S, Xia J, Chen Z, Zhang S, Ahmad A, Miele L, Sarkar FH, Wang Z: Inhibitory effect of curcumin on oral carcinoma CAL-27 cells via suppression of Notch-1 and NF- $\mathrm{KB}$ signaling pathways. J Cell Biochem, 2011, $112,1055-1065$.

20. Liu YJ: Thymic stromal lymphopoietin: master switch for allergic inflammation. J Exp Med, 2006, 203, 269-273.

21. Mancini AJ, Kaulback K, Chamlin SL: The socioeconomic impact of atopic dermatitis in the United States: a systematic review. Pediatr Dermatol, 2008, 25, 1-6.

22. Moon PD, Choi IH, Kim HM: Epigallocatechin-3-Ogallate inhibits the production of thymic stromal lymphopoietin by the blockade of caspase-1/NF- $\mathrm{KB}$ pathway in mast cells. Amino Acids, 2012, 42, 2513-2519.

23. Moon PD, Kim HM: Thymic stromal lymphopoietin is expressed and produced by caspase- $1 / \mathrm{NF}-\kappa \mathrm{B}$ pathway in mast cells. Cytokine, 2011, 54, 239-243.

24. Oh HA, Ryu JG, Cha WS, Kim HM, Jeong HJ: Therapeutic effects of traditional Korean medicine, JeechoolWhan in allergic rhinitis model. Tang, 2012, 2, e9.

25. Oiwa M, Satoh T, Watanabe M, Niwa H, Hirai H, Nakamura M, Yokozeki H: CRTH2-dependent, STAT6independent induction of cedar pollen dermatitis. Clin Exp Allergy, 2008, 38, 1357-1366.

26. Ozawa T, Koyama K, Ando T, Ohnuma Y, Hatsushika K, Ohba T, Sugiyama H et al.: Thymic stromal lymphopoietin secretion of synovial fibroblasts is positively and negatively regulated by toll-like receptors/nuclear fac tor- $\kappa \mathrm{B}$ pathway and interferon- $\gamma /$ dexamethasone. Mod Rheumatol, 2007, 17, 459-463.

27. Rafiee P, Nelson VM, Manley S, Wellner M, Floer M, Binion DG, Shaker R: Effect of curcumin on acidic $\mathrm{pH}-$ induced expression of IL-6 and IL-8 in human esophageal epithelial cells (HET-1A): role of PKC, MAPKs, and NF-кB. Am J Physiol Gastrointest Liver Physiol, 2009, 296, G388-398.

28. Reefer AJ, Hulse KE, Lannigan JA, Solga MD, Wright PW, Kelly LA, Patrie J et al.: Flow cytometry imaging identifies rare $\mathrm{T}_{\mathrm{H}} 2$ cells expressing thymic stromal lymphopoietin receptor in a "proallergic" milieu. J Allergy Clin Immunol, 2010, 126, 1049-1058.

29. Sanmukhani J, Anovadiya A, Tripathi CB: Evaluation of antidepressant like activity of curcumin and its combination with fluoxetine and imipramine: an acute and 
chronic study. Acta Pol Pharm Drug Res, 2011, 68, 769-775.

30. Schneider C, Döcke WD, Zollner TM, Röse L: Chronic mouse model of TMA-induced contact hypersensitivity. J Invest Dermatol, 2009, 129, 899-907.

31. Wakade C, King MD, Laird MD, Alleyne Jr CH, Dhandapani KM: Curcumin attenuates vascular inflammation and cerebral vasospasm after subarachnoid hemorrhage in mice. Antioxid Redox Signal, 2009, 11, 35-45.

32. Waly MI, Al Moundhri MS, Ali BH: Effect of curcumin on cisplatin- and oxaliplatin-induced oxidative stress in human embryonic kidney (HEK) 293 cells. Ren Fail, 2011, 33, 518-523.
33. Xiong Z, Hongmei Z, Lu S, Yu L: Curcumin mediates presenilin- 1 activity to reduce $\beta$-amyloid production in a model of Alzheimer's Disease. Pharmacol Rep, 2011, 63, 1101-1108.

34. Ziegler SF: The role of thymic stromal lymphopoietin (TSLP) in allergic disorders. Curr Opin Immunol, 2010, 22, 795-799.

Received: March 8, 2012; in the revised form: November 14, 2012; accepted: November 26, 2012. 